\title{
Impact of the Application of IFRS 15 on the Profitability of Jordanian Telecom Companies (Case Study: Jordan Orange Telecom)
}

\author{
Ola Mohammad Khersiat ${ }^{1}$ \\ ${ }^{1}$ Accounting Department, Faculty of Economics and Administration Sciences, Zarqa University, Jordan \\ Correspondence: Ola Mohammad Khersiat, Accounting Department, Zarqa University, Zarqa 13110, Jordan.
}

Received: October 6, 2020

Accepted: November 4, 2020

Online Published: January 14, 2021

doi:10.5430/ijfr.v12n2p308

URL: https://doi.org/10.5430/ijfr.v12n2p308

\begin{abstract}
This study investigates the impact of applying IFRS 15 standard on the profitability of Jordanian telecommunications companies (case study: Jordan Orange Telecom). The study addresses three independent variables, namely, contract revenue, customer contract assets and customer contract liabilities and their impact on the ROA, ROE and PM in Orange Jordan. The researcher has investigated the relationship and impact of the independent variables on dependent variables by analysing financial statements after applying IFRS15 for 2017, 2018, 2019. The study concludes that there is a relationship and impact between contract revenue and ROA and ROE, where the correlation coefficient amounted to $(99.8,99.0)$ respectively, with a level of significance $(0.02,0.04)$. The coefficient of determination (R2) amounted to (99.6\%), indicating that contract revenue interprets $(99.6 \%)$ of the return on assets in Orange Telecom. Also, the coefficient of determination (R2) amounted to (99.9\%), indicating that contract revenues interpret $(99.9 \%)$ of the ROE in Orange Telecom. The correlation coefficient between contract revenue and PM amounted to (99.2) with a level of significance (0.08), where a correlation relationship is noticed but with a level of significance exceeding (0.05). As for customer contract assets and customer contract liabilities, no relationship or impact is found betweem these and ROA, ROE and PM in Jordan Orange Telecom. Accordingly, the study recommends that companies in Jordan should abide by IFRS15 in order to increase corporate profitability.
\end{abstract}

Keywords: IFRS15, Retrun on Assets (ROA), Retrun on Equity (ROE), Profit Margain (PM), contract revenue, contract assets, contract liabilities, profitability

\section{Introduction}

Revenue in income statement is a fundamental element, resulting from operational processes in the company. It reflects the size of its activity and is considered one of the basic standards to evaluate corporate performance. Within the efforts endeavoured by the International Accounting Standards Board (IASB), and the American Financial Accounting Standards Board (FASB), the Financial Reporting Standard 15 has been issued. The standard addresses how to recognise revenues, identifies its terms as well as focuses on the importance of ensuring a full achievement of the revenue to be recognised in financial statements, provided that it does not conflict with the conceptual framework of financial statements. This standard has substituted the IAS11 and IAS18 standards since these did not present a clear policy of revenue recognition, and showed a contradiction in revenue recognition requirements. The IFRS15 has set five steps to revenue recognition, namely, identifying contracts with customers, identifying performance liabilities in contracts, determining the transaction price, allocating the liabilities transaction price, and preparing and recognizing revenue in case performance liabilities have been fulfilled. (IFRS 15)

This standard aims to improve the comparison of financial statements between practices that achieve different revenues, as well as provide useful information for decision-making of financial statements users. This is achieved through disclosure of most operational activities that increase company revenue and improve the process of preparing financial statements. The importance of this standard lies in recognising revenue in cases when this is not easily or directly done, in the light of the methods adopted by companies to grant advantages to their customers such as in the offerings of telecommunications companies which present landlines, cellular, Internet and SMS services in one package. (IFRS 15)

Some global companies have applied this standard early. Rolls-Royce in the UK has declared that profits will decline due to the application of this standard. Their profits declined in 2015, before the application of the standard, from 1.4 billion pounds to less than 900 million pounds after the application of the standard. This is due to the fact that it 
depends on services contracts to make a profit and compensate loss in the financial position statement. The company would sell aircraft engines with a loss of 1-2 million pounds since it held after-sale revenue in advance, which is rejected by IFRS15, since losses should be reported immediately without holding revenue till the customer provides the service. David Smith has acknowledged that applying IFRS15 shall improve the financial performance.

Therefore, this study investigates the impact of applying IFRS 15 standard on the profitability of telecommunications companies (Case study: Jordan Orange).

\section{Literature Review}

Several studies have examined the IFRS15 and its impact on profit sustainability. Khalil Ibrahim (2017) and YacoubSchnichl (2018) have concluded that the application of the standard positively affects the sustainability of profits and that there is a strong correlation between IFRS15 and the sustainability of profits. Moreover, the studies suggest changing the accounting system to be in line with IFRS15 requirements.

Ani, MCT (2019) has addressed the impact of IFRS15 on financial reporting. The study concluded that corporates shall be equipped to apply the standard. Moreover, applying the standard has an impact on the quality of financial reporting in corporate financial statements.

Kasztelnik (2015) has aimed at identifying the change in the value of revenue achievement based on IFRS15 in the USA. The study concluded that revenue recognition is related to general accepted accounting principles and will remain so after the application of IFRS15.

Lim et al. (2015) and Khamis (2016) have indicated how auditors and preparers perceive IFRS15 in Malaysia and Egypt. The two studies have concluded that auditors and preparers believe that corporates in both countries are not fully prepared to apply the standard, which cannot be easily applied in all different sectors. The studies recommend that auditors and preparers shall be well trained to have a comprehensive and thorough understanding of IFRS15.

Ozerhan, Bilkent (2019) has concluded that IFRS15 has not brought any changes to Turkish companies since their corporate contracts are individual, while trading companies in Europe and USA Stock Exchanges have been affected by the standard. This has been disclosed in the explanations attached to the financial statements.

\section{Research Methodology}

\subsection{Hypothesis Testing}

\subsubsection{Main Hypothesis}

H0: there is no impact of the application of IFRS 15 standard to the profitability of Jordanian telecommunications companies (Case study: Jordan Orange)

The following sub-hypotheses fall under the main one:

H01: There is no statistically significant impact of the application of IFRS 15 standard on the relationship between contract revenue and ROA in Jordanian telecommunications companies.

H0 2: There is no statistically significant impact of the application of IFRS 15 standard on the relationship between contract revenue and ROE in Jordanian telecommunications companies.

H0 3: There is no statistically significant impact of the application of IFRS 15 standard on the relationship between contract revenue and PM in Jordanian telecommunications companies.

H0 4: There is no statistically significant impact of the application of IFRS 15 standard on the relationship between contract assets and ROA in Jordanian telecommunications companies.

H0 5: There is no statistically significant impact of the application of IFRS 15 standard on the relationship between contract assets and ROE in Jordanian telecommunications companies.

H0 6: There is no statistically significant impact of the application of IFRS 15 standard on the relationship between contract assets and PM in Jordanian telecommunications companies.

H0 7: There is no statistically significant impact of the application of IFRS 15 standard on the relationship between contract liabilities and ROA in Jordanian telecommunications companies.

H0 8: There is no statistically significant impact of the application of IFRS 15 standard on the relationship between contract liabilities and ROE in Jordanian telecommunications companies.

H0 9: There is no statistically significant impact of the application of IFRS 15 standard on the relationship between contract liabilities and PM in Jordanian telecommunications companies. 


\subsubsection{Hypothesis Testing}

To verify the hypotheses, the researcher applies Pearson correlation coefficient to investigate the relationship and its strength between the independent variable, IFRS15, represented in (contract revenues, contract assets and contract liabilities) and the dependent variable, profitability, represented in (ROA, ROE, PM). The multiple regression analysis is used to clarify the impact of the relationship between independent and dependent variables and the coefficient of determination to measure the impact size, which represents the relationship between independent and dependent variables, and to determine the impact of the application of the IFRS15 on the profitability of Jordanian telecommunications companies (Case Study: Jordan Orange for 2017, 2018, 2019).

Testing H01: There is no statistically significant impact of the application of IFRS 15 standard on the relationship between contract revenue and ROA in Jordanian telecommunications companies.

Table 1. Pearson correlation

\begin{tabular}{lll}
\hline Pearson Correlation & & R.A \\
\hline T.R & Pearson Correlation & $.998^{*}$ \\
\cline { 2 - 3 } & Sig. (tailed-2) & .041 \\
\cline { 2 - 3 } & $\mathrm{N}$ & 3 \\
\hline
\end{tabular}

Table 1 shows Pearson correlation coefficient between contract revenue and ROA. It indicates that there is a strong correlation of statistical significance at a significance level of $(\alpha \leq 0.05)$, where the the correlation coefficient between them reached $\left(.998^{*}\right)$ at the level of significance (.041), indicating the presence of a strong correlation of statistical significance between contract revenue and ROA after the application of IFRS15 through 2017, 2018, 2019.

In order to determine the impact of IFRS15 on the relationship between contract revenue and ROA in Jordanian telecommunication companies and measure the impact of such a relationship, the simple linear regression analysis has been used as shown in Table 2 .

Table 2. ANOVA

\begin{tabular}{llllllll}
\hline Model & & Sum of Squares & Df & Mean Square & F & Sig. & R Square \\
\hline 1 & Regression & .405 & 1 & .405 & 242.193 & $.041 \mathrm{~b}$ & .996 \\
\cline { 2 - 7 } & Residual & .002 & 1 & .002 & & & \\
\cline { 2 - 7 } & Total & .407 & 2 & & & & \\
\hline
\end{tabular}

Table 2 shows that: There is an impact of significance at the level of significance $(\leq 0.05)$ where the calculated value of "F" amounted to (242.193) at a level of significance (.041b), and the value of the coefficient of determination (R2) was $(99.6 \%)$. This indicates that contract revenue interprets (99.6\%) of ROA in Jordan Orange, and the rest, which amounts to $(.002 \%)$ is due to other factors. Therefore, hypothesis H01stating that: there is no impact of significance to the application of IFRS 15 on the relationship between contract revenues and ROA in Orange Telecom is rejected.

Table 3. Coefficients

\begin{tabular}{lllllll}
\hline \multirow{2}{*}{ Model } & & \multicolumn{2}{l}{ Unstandardized Coefficients } & \multicolumn{2}{l}{ Standardized Coefficients } & \\
\cline { 2 - 6 } & & B & Std. Error & Beta & T & Sig. \\
\hline \multirow{2}{*}{ (Constant) } & -16.766 & 1.292 & & -12.979 & .049 \\
\cline { 2 - 6 } T.R & $6.176 \mathrm{E}-8$ & .000 & .998 & 15.563 & .041 \\
\hline
\end{tabular}

Table 3 shows, after conducting the $\mathrm{T}_{-}$test, that the model parameters estimations as per the constant, and contract revenues indicated a statistical significance at the level of significance $(\alpha \leq 0.05)$, where the calculated value of "T" 
amounted to $(-12.979,15.563)$ respectively at a level of significance $(.041, .049)$ respectively. Therefore, the regression equation can be written as follows:

\section{$\mathrm{ROA}=16.766-6.176$ (contract revenues)}

Thus, the relationship between contract revenues and return on assets at Orange Telecom is strong, inverse and statistically significant.

H0 2: There is no statistically significant impact of the application of IFRS 15 standard on the relationship between contract revenue and ROE in Jordanian telecommunications companies.

Table (1-4) shows Pearson correlation coefficient between contract revenue and ROE. It indicates that there is a strong correlation of statistical significance at a significance level of $(\alpha \leq 0.05)$, where the the correlation coefficient between them, as shown in Table 4, reached (.999*) at the level of significance (.024), indicating the presence of a strong correlation of statistical significance between contract revenue and ROE after the application of IFRS15 through 2017, 2018, 2019.

Table 4. Pearson correlation

\begin{tabular}{lll}
\hline Pearson Correlation & & R.E \\
\hline \multirow{2}{*}{ T.R } & Pearson Correlation & $.999^{*}$ \\
\cline { 2 - 3 } & Sig. (tailed-2) & .024 \\
\cline { 2 - 3 } & $\mathrm{N}$ & 3 \\
\hline
\end{tabular}

To determine the impact of applying IFRS 15 on the relationship between contract revenue and ROE Jordanian telecommunications companies, and measure the impact size of the relationship, the simple linear regression analysis has been used as shown in Table 5 .

Table 5. ANOVA

\begin{tabular}{llllllll}
\hline Model & & Sum of Squares & Df & Mean Square & F & Sig. & R Square \\
\hline 1 & Regression & 1.817 & 1 & 1.817 & 717.259 & $.024 b$ & .999 \\
\cline { 2 - 7 } & Residual & .003 & 1 & .003 & & & \\
\cline { 2 - 7 } & Total & 1.820 & 2 & & & & \\
\hline
\end{tabular}

Table 5 shows that there is an impact of significance at the level of significance $(\leq 0.05)$ where the calculated value of "F" amounted to (717.259) at a level of significance (.024b), and the value of the coefficient of determination (R2) was (99.9\%). This indicates that contract revenue interprets (99.9\%) of ROE in Jordan Orange, and the rest, which amounts to $(.003 \%)$ is due to other factors. Therefore, hypothesis $\mathrm{H} 02$ stating that: there is no impact of significance to the application of IFRS 15 on the relationship between contract revenues and ROE in Orange Telecom is rejected.

Table 6. Coefficients

\begin{tabular}{lllllll}
\hline \multirow{2}{*}{ Model } & & \multicolumn{2}{l}{ Unstandardized Coefficients } & \multicolumn{2}{l}{ Standardized Coefficients } & \\
\cline { 2 - 7 } & & B & Std. Error & Beta & T & Sig. \\
\hline 1 & (Constant) & -34.679 & 1.590 & & -21.809 & .029 \\
\cline { 2 - 6 } & T.R & $1.308 \mathrm{E}-7$ & .000 & .999 & 26.782 & .024 \\
\hline
\end{tabular}

Table 6 shows, after conducting the $T_{-}$test, that the model parameters estimations as per the constant, and contract revenues indicated a statistical significance at the level of significance $(\alpha \leq 0.05)$, where the calculated value of "T" amounted to (26.782)and (-21.809), respectively, at a level of significance (.024) and (.029), respectively. Therefore, the regression equation can be written as follows: 


$$
\mathrm{ROE}=34.679-1.308 \text { (contract revenue) }
$$

The end result is that the relationship between contract revenue and the ROE in Orange Telecom is strong, inverse and statistically significant conforming to Khalil, Ibrahim (2017) and YacoubSchnichl (2018) which state that IFRS15 has an impact on the sustainability of profits and improvement of corporates financial performance.

H0 3: There is no statistically significant impact of the application of IFRS 15 on the relationship between contract revenue and PM in Jordanian telecommunications companies.

Table 7. Pearson correlation

\begin{tabular}{llll}
\hline Pearson Correlation & & T.R & P.M \\
\hline T.R & Pearson Correlation & 1 & .992 \\
\cline { 2 - 4 } & Sig. (tailed-2) & & .082 \\
\cline { 2 - 3 } & $\mathrm{N}$ & 3 & 3 \\
\hline
\end{tabular}

Table 7 shows Pearson correlation coefficient between contract revenue and PM. It indicates that there is a strong correlation of statistical significance at a significance level of $(\alpha \leq 0.05)$, where the the correlation coefficient between them, as shown in Table 7, reached (.992*) at the level of significance (.08), indicating the presence of a strong correlation of statistical significance between contract revenue and PM after the application of IFRS15 through 2017, 2018, 2019.

Table 8. ANOVA

\begin{tabular}{llllllll}
\hline Model & & Sum of Squares & Df & Mean Square & F & Sig. & R Square \\
\hline 1 & Regression & .708 & 1 & .708 & 60.150 & $.082 \mathrm{~b}$ & .984 \\
\cline { 2 - 7 } & Residual & .012 & 1 & .012 & & & \\
\cline { 2 - 6 } & Total & .720 & 2 & & & & \\
\hline
\end{tabular}

Table 8 shows that there is no impact of significance at the level of significance $(\leq 0.05)$, where the calculated value of "F" amounted to (60.150) at a level of significance (.082b), and the value of the coefficient of determination (R2) was (.984\%). This indicates that contract revenue interprets (98.4\%) of PM in Jordan Orange, and the rest, which amounts to $(.012 \%)$ is due to other factors. Therefore, hypothesis H03 stating that: there is no impact of significance to the application of IFRS 15 on the relationship between contract revenues and PM in Orange Telecom is accepted.

H0 4: There is no statistically significant impact of the application of IFRS 15 standard on the relationship between contract assets and ROA in Jordanian telecommunications companies.

Table 9. Pearson correlation

\begin{tabular}{lll}
\hline Pearson Correlation & & R.A \\
\hline ASS.CON & Pearson Correlation & -.493 \\
\cline { 2 - 3 } & Sig. (tailed-2) & .672 \\
\cline { 2 - 3 } $\mathrm{N}$ & 3 \\
\hline
\end{tabular}

Table 9 shows that the Pearson correlation coefficient between contract assets and ROA does not indicate the presence of a strong relationship and of statistical significance at the level of significance $(\alpha \leq 0.05)$, where the correlation coefficient between them, as shown in Table 9, amounted to $\left(-.493^{*}\right)$ at a level of significance (.672), which indicates that there is no strong and statistically significant correlation between contract revenue and ROA after the application of the IFRS15 through 2017, 2018 and 2019. 
Table 10. ANOVA ${ }^{\mathrm{a}}$

\begin{tabular}{|c|c|c|c|c|c|c|c|}
\hline$\overline{\text { Model }}$ & & Sum of Squares & & Mean Square & $\mathrm{F}$ & Sig. & R Square \\
\hline \multirow[t]{3}{*}{1} & Regression & .099 & 1 & .099 & .321 & $.672 b$ & .243 \\
\hline & $\overline{\text { Residual }}$ & .308 & 1 & .308 & & & \\
\hline & Total & .407 & 2 & & & & \\
\hline
\end{tabular}

Table 10 shows that here is no impact of significance at the level of significance $(\leq 0.05)$, where the calculated value of "F" amounted to (.321) at a level of significance (.672b), and the value of the coefficient of determination (R2) was $(243 \%)$. This indicates that contract assets interpret (24.3\%) of ROA in Jordan Orange, and the rest, which amounts to $(.308 \%)$ is due to other factors. Therefore, hypothesis H04 stating that: there is no impact of significance to the application of IFRS 15 on the relationship between contract assets and ROA in Orange Telecom is accepted.

H0 5: There is no statistically significant impact of the application of IFRS 15 on the relationship between contract assets and ROE in Jordanian telecommunications companies.

Table 11. Pearson correlation

\begin{tabular}{lll}
\hline Pearson Correlation & & R.E \\
\hline ASS.CON & Pearson Correlation & -.516 \\
\cline { 2 - 3 } Sig. (tailed-2) & .655 \\
\cline { 2 - 3 } $\mathrm{N}$ & 3 \\
\hline
\end{tabular}

Table 11 shows Pearson correlation coefficient between contract revenue and ROE. It indicates that there is not a strong correlation of statistical significance at a significance level of $(\alpha \leq 0.05)$, where the correlation coefficient between them, as shown in Table (1-11), reached (.-516*) at the level of significance (.655), indicating the absence of a strong correlation of statistical significance between contract revenue and ROE after the application of IFRS15 through 2017, 2018, 2019.

Table 12. ANOVA

\begin{tabular}{llllllll}
\hline Model & & Sum of Squares & Df & Mean Square & F & Sig. & R Square \\
\hline 1 & Regression & .484 & 1 & .484 & .363 & $655 . b$ & .266 \\
\cline { 2 - 8 } & Residual & 1.336 & 1 & .1 .336 & & & \\
\cline { 2 - 7 } & Total & .1 .820 & 2 & & & & \\
\hline
\end{tabular}

Table 12 There is no impact of significance at the level of significance $(\leq 0.05)$, where the calculated value of " $F$ " amounted to (.363) at a level of significance (.655b), and the value of the coefficient of determination (R2) was $(.266 \%)$. This indicates that contract assets interpret (26.6\%) of ROE in Jordan Orange, and the rest, which amounts to $(.266 \%)$ is due to other factors. Therefore, hypothesis H05 stating that: there is no impact of significance to the application of IFRS 15 on the relationship between contract assets and ROE in Orange Telecom is accepted.

H0 6: There is no statistically significant impact of the application of IFRS 15 on the relationship between contract assets and PM in Jordanian telecommunications companies.

Table 13. Pearson correlation

\begin{tabular}{lll}
\hline Pearson Correlation & & P.M \\
\hline ASS.CON & Pearson Correlation & -.436 \\
\cline { 2 - 3 } & Sig. (tailed-2) & .713 \\
\cline { 2 - 3 } $\mathrm{N}$ & 3 \\
\hline
\end{tabular}


Table 13 shows Pearson correlation coefficient between contract assets and PM. It indicates that there is not a strong correlation of statistical significance at a significance level of $(\alpha \leq 0.05)$, where the the correlation coefficient between them, as shown in Table (1-13), reached (.436*) at the level of significance (.713), indicating the absence of a strong correlation of statistical significance between contract assets and PM after the application of IFRS15 through 2017, 2018, 2019.

Table 14. ANOVA

\begin{tabular}{llllllll}
\hline Model & & Sum of Squares & Df & Mean Square & F & Sig. & R Square \\
\hline & Regression & .137 & 1 & .137 & .583 & 713 b. & .190 \\
\cline { 2 - 8 } & Residual & .583 & 1 & .583 & & & \\
\cline { 2 - 8 } & Total & .720 & 2 & & & & \\
\hline
\end{tabular}

Table 14 There is no impact of significance at the level of significance $(\leq 0.05)$, where the calculated value of "F" amounted to (.583) at a level of significance (.713b), and the value of the coefficient of determination (R2) was $(.19 .0 \%)$. This indicates that contract assets interpret (19.0\%) of PM in Jordan Orange, and the rest, which amounts to $(.583 \%)$ is due to other factors. Therefore, hypothesis $\mathrm{H} 06$ stating that: there is no impact of significance to the application of IFRS 15 on the relationship between contract assets and PM in Orange Telecom, is accepted.

H0 7: There is no statistically significant impact of the application of IFRS 15 on the relationship between contract liabilities and ROA in Jordanian telecommunications companies.

Table 15. Pearson correlation

\begin{tabular}{lll}
\hline Pearson Correlation & & R.A \\
\hline LIA.CON & Pearson Correlation & .649 \\
\cline { 2 - 3 } & Sig. (tailed-2) & .550 \\
\cline { 2 - 3 } & $\mathrm{N}$ & 3 \\
\hline
\end{tabular}

Table 15 shows Pearson correlation coefficient between contract liabilities and ROA. It indicates that there is not a strong correlation of statistical significance at a significance level of $(\alpha \leq 0.05)$, where the the correlation coefficient between them, as shown in Table (1-15), reached (.649) at the level of significance (.550), indicating the absence of a strong correlation of statistical significance between contract liabilities and ROA after the application of IFRS15 through 2017, 2018, 2019.

Table 16. ANOVA

\begin{tabular}{|c|c|c|c|c|c|c|c|}
\hline Model & & Sum of Squares & $\overline{\mathrm{Df}}$ & Mean Square & $\mathrm{F}$ & Sig. & R Square \\
\hline & Regression & .171 & 1 & .171 & .728 & $550 . \mathrm{b}$ & .421 \\
\hline & Residual & .235 & 1 & .235 & & & \\
\hline & Total & .407 & 2 & & & & \\
\hline
\end{tabular}

Table 16 shows that there is no impact of significance at the level of significance $(\leq 0.05)$, where the calculated value of "F" amounted to (.728) at a level of significance (.550b), and the value of the coefficient of determination (R2) was $(.42 .1 \%)$. This indicates that contract assets interpret (42.1\%) of ROA in Jordan Orange, and the rest, which amounts to $(.235 \%)$ is due to other factors. Therefore, hypothesis $\mathrm{H} 07$ stating that: there is no impact of significance to the application of IFRS 15 on the relationship between contract liabilities and ROA in Orange Telecom, is accepted.

H0 8: There is no statistically significant impact of the application of IFRS 15 on the relationship between contract liabilities and ROE in Jordanian telecommunications companies. 
Table 17. Pearson correlation

\begin{tabular}{lll}
\hline Pearson Correlation & & R.E \\
\hline LIA.CON & Pearson Correlation & .669 \\
\cline { 2 - 3 } Sig. (tailed-2) & .533 \\
\cline { 2 - 3 } $\mathrm{N}$ & 3 \\
\hline
\end{tabular}

Table 17 shows Pearson correlation coefficient between contract liabilities and ROE. It indicates that there is not a strong correlation of statistical significance at a significance level of $(\alpha \leq 0.05)$, where the the correlation coefficient between them, as shown in Table (1-17), reached (.669) at the level of significance (.533), indicating the absence of a strong correlation of statistical significance between contract liabilities and ROE after the application of IFRS15 through 2017, 2018, 2019.

Table 18. ANOVA ${ }^{\mathrm{a}}$

\begin{tabular}{llllllll}
\hline Model & & Sum of Squares & Df & Mean Square & F & Sig. & R Square \\
\hline 1 & Regression & .815 & 1 & .815 & .811 & $533 . b$ & .448 \\
\cline { 2 - 8 } & Residual & 1.005 & 1 & 1.005 & & & \\
\cline { 2 - 8 } & Total & 1.820 & 2 & & & & \\
\hline
\end{tabular}

Table 18 shows that There is no impact of significance at the level of significance $(\leq 0.05)$, where the calculated value of " $\mathrm{F}$ " amounted to (.811) at a level of significance (.533b), and the value of the coefficient of determination (R2) was (.44.8\%). This indicates that contract liabilities interpret (44.8\%) of ROE in Jordan Orange, and the rest, which amounts to $(1.005 \%)$ is due to other factors. Therefore, hypothesisH08 stating that: there is no statistically significant impact of applying IFRS 15 to the relationship between contract liabilities in Jordan Orange is accepted.

H0 9: There is no statistically significant impact of the application of IFRS 15 on the relationship between contract liabilities and PM in Jordanian telecommunications companies.

Table 19. Pearson correlation

\begin{tabular}{lll}
\hline Pearson Correlation & & P.M \\
\hline LIA.CON & Pearson Correlation & .599 \\
\cline { 2 - 3 } & Sig. (tailed-2) & .591 \\
\cline { 2 - 3 } & $\mathrm{N}$ & 3 \\
\hline
\end{tabular}

Table 19 shows Pearson correlation coefficient between contract liabilities and PM. It indicates that there is not a strong correlation of statistical significance at a significance level of $(\alpha \leq 0.05)$, where the the correlation coefficient between them, as shown in Table (1-19), reached (.599) at the level of significance (.591), indicating the absence of a strong correlation of statistical significance between contract liabilities and PM after the application of IFRS15 through 2017, 2018, 2019.

Table 20. ANOVA ${ }^{\mathrm{a}}$

\begin{tabular}{llllllll}
\hline Model & & Sum of Squares & Df & Mean Square & F & Sig. & R Square \\
\hline 1 & Regression & .258 & 1 & .258 & .560 & $591 . b$ & .359 \\
\cline { 2 - 7 } & Residual & .462 & 1 & .462 & & & \\
\cline { 2 - 7 } & Total & .720 & 2 & & & & \\
\hline
\end{tabular}


Table 20 There is no impact of significance at the level of significance $(\leq 0.05)$, where the calculated value of "F" amounted to $(.560)$ at a level of significance $(.591 \mathrm{~b})$, and the value of the coefficient of determination (R2) was (.35.9\%). This indicates that contract liabilities interpret (35.9\%) of PM in Jordan Orange, and the rest, which amounts to $(.462 \%)$ is due to other factors. Therefore, hypothesis H09 stating that: there is no statistically significant impact of applying IFRS 15 to the relationship between contract liabilities and PM in Jordan Orange, is accepted.

To test the main hypothesis which states that: HO there is no impact to the application of IFRS15 on the profitability of Jordanian Telecommunications companies (Case study: Jordan Orange), an impact of contract revenues on ROE and ROA is only found, whereas no such impact on PM is noticed since Siq value exceeds 0.05, while contract assets and contract liabilities have no impact or relationship to ROA, ROE and PM.

\section{Conclusions and Recommendations}

Results indicate that there is a relationship and impact between contract revenues, namely, voice services revenues, data services revenues and other services revenues and ROA and ROE, where the correlation coefficient amounted to ( $99.8,99.9)$ respectively at a level of significance $(0.02,0.04)$. The value of the coefficient of determination (R2) reached $(99.6 \%)$, indicating that contract revenues interpret $(99.6 \%)$ of the return on assets at Jordan Orange. Moreover, the value of the coefficient of determination (R2) reached (99.9\%), indicating that contract revenues interpret $(99.9 \%)$ of ROE in Jordan Orange. The correlation coefficient between contract revenues and PM reached 99.2, al a level of significance (0.08), where a strong correlation is found at a level of significance exceeding (0.05). Regarding customers` contract revenues as required by the " customers` contract revenues" standard, and due to the contrast in timing between revenues realization and issuance of customers invoices, which mostly result from packages offers that combine both selling equipment and providing other short-term services, where equipment invoices are issued at low cost, resulting in a redistribution of part of the revenues which are generated from providing other services services related to equipment sale revenues, customers contract assets are acknowledged by the difference between re-distributed equipment sale revenues and the amount of money to which an invoice is issued. Therefore, no relationship or impact is found between customers' contract revenues and ROA, ROE and PM. On the other hand, customers contract liabilities are the amounts paid to customers prior to receiving the merchandise or the service as agreed upon and stated in the contract. This is similar to when the group is paid directly from the client in advance or customers' bills are reimbursed before the group transfer the merchandise or service, such as contract obligations or prepaid services (which have been proved previously as deferred revenues). So, no relationship or impact is found between these and ROE, ROA and PM. Accordingly, the study recommends that Jordanian corporates shall abide by IFRS15 so as to increase corporate profitability since the application of this standard determines the conditions of revenue recognition as it focuses on the need to ensure full achievement of the revenue to be recognized in financial statements, as well as providing disclosure rules that ensure a clear presentation of financial statements.

\section{References}

Ani, S., \& Mct, A. (2019). Effect of the application of IFRS 15 "Revenue from contracts with customers" on the quality of financial reporting. Journal of Economics and Administrative Sciences, 25(113).

Gibson, C. (2012). Financial Reporting and Analysis: Using Financial Accounting Information (12th ed.). International Financial Reports standard (IFRS) "IFRS 15 - Revenue from Contracts with Customers" (On-line). Retrieved from http://ifrs.org

Kasztelnik, K. (2015). The value relevance of revenue recognition under international financial reporting standards. Accounting and Finance Research, 3(4), 88-98. https://doi.org/10.5430/afr.v4n3p88

Khalil, A., \& Ibrahim, M. (2017). Measuring impact of applying revenue standard from contracts with customers IFRS 15 on sustainability of accounting earnings-Evidence from the Egyptian environment. AUJAA, 5(1), 1-60. https://doi.org/10.24815/jdab.v3i2.5383

Khamis, A. (2016). Perception of Preparers and Auditors on Revenue from Contract with Customer (IFRS 15): Evidence from Egypt. Proceedings of 35th International Business Research Conference (pp. 1-19). American University in the Emirates, Dubai, UAE.

Lim, Y., Devi, S., \& Mahzan, N. (2015). Perception of Auditors and Preparers on IFRS 15: Evidence from Malaysia. Advanced Science Letters, 6(21), 1781-1785. https://doi.org/10.1166/asl.2015.6212 
Ozerhan, Y., \& Bilkent, S. (2019). Accounting of Licensing Under TFRS 15: A Research on Software Industry. The Journal of Accounting and Finance- August 2019 Special Issue, 1(4), 15-32. https://doi.org/10.25095/mufad.605917

Yacoub, E., \& Schnichl, A. (2018). The role of implementing the revenue standard from contracts with customers FRS 15 (in the sustainability of profits in the telecommunications sector, an applied study in Korek Telecom Company. Journal of Accounting and Financial Studies, Special Issue-The First Scientific Conference, 1-38.

\section{Copyrights}

Copyright for this article is retained by the author(s), with first publication rights granted to the journal.

This is an open-access article distributed under the terms and conditions of the Creative Commons Attribution license (http://creativecommons.org/licenses/by/4.0/). 